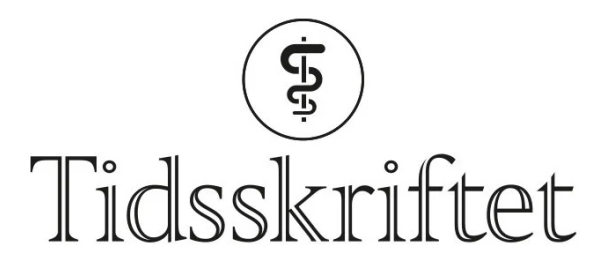

DEN NORSKE LEGEFORENING

\title{
Kvalitetskontroll av implanterte hjertestartere
}

LEDER

\section{TORKEL STEEN}

tostenn@online.no

Torkel Steen er spesialist i indremedisin og hjertesykdommer og dr. med. Han er overlege ved Pacemaker- og ICD-senteret, Hjerteavdelingen, Oslo universitetssykehus Ullevål, Han er tidligere leder for Norsk pacemakerregister og er nå prosjektleder for et nytt, interregionalt behandlingsregister for pacemaker og hjertestarterimplantasjon i regi av Helse Sør- $\emptyset$ st. Forfatter har fylt ut ICMJE-skjemaet og oppgir ingen interessekonflikter.

\section{Kvalitetsovervåkning er nøkkelen til god pasientsikkerhet. «Personvern» må ikke stå i veien.}

Nyman og medarbeidere har studert hvordan det gikk med pasientene som fikk implantert hjertestarter (implantable cardioverter defibrillator, ICD) på St. Olavs hospital gjennom ni år (1). Dermed kan de sammenlikne sin praksis med det som er rapportert i annet publisert materiale. Er indikasjonsstillingen som ved andre sentra? Har man omtrent samme forekomst av komplikasjoner? Eventuelle påfallende forskjeller kan lede til endringer.

St. Olavs hospital kan være stolt av relativt få komplikasjoner i sitt materiale. Men ICDbehandling er ikke komplikasjonsfritt: 8 \% av pasientene måtte reopereres for å rette feil ved ledninger eller ICD-anlegget. 2 \% fikk infeksjon, hvilket er relativt lite og dermed en god kvalitetsindikator.

11 \% av pasientene fikk uberettigede støt, dvs. støt på annet enn ventrikkelarytmi, fra sin hjertestarter. Dette er en kjent og traumatisk bivirkning ved ICD-behandling. Heldigvis har forekomsten av uberettigede støt vært avtakende de senere år, slik man også ser i denne kohorten. I hovedsak skyldes det mer «konservativ» programmering, dvs. at den implanterte hjertestarteren gjøres tregere på avtrekkeren. Arytmien skal vare lenger og være hissigere for at terapi skal utløses.

$26 \%$ fikk berettigede støt, dvs. støt utløst av ventrikkelarytmi. Det er lett å tenke at et støt «redder pasientens liv». Det er dessverre en feilslutning. Mange ventrikkelarytmier går over av seg selv. I AVID-studien med pasienter som hadde hatt hjertestans eller livstruende arytmi (sekundærprofylakse), var ratio mellom sjokk i ICD-gruppen og plutselig hjertedød i gruppen uten implantert hjertestarter hele 6,6 (2) $)$. I SCD-HeFT-studien med pasienter med $\emptyset \mathrm{kt}$ risiko for livstruende arytmi (primærprofylakse), var ratioen 5,7 (ㅁ). 
Hvor stor er så overlevelseseffekten? I en metaanalyse av de tre store sekundærprofylaksestudiene var relativ risikoreduksjon $28 \%$ for totalmortalitet og 50 \% for arytmimortalitet (3). Men den absolutte risikoreduksjonen var «bare» 3,5\%, svarende til en NNT-verdi (antall pasienter som må behandles for å unngå en hendelse) på 29 per år. I SCDHeFT-studien ga behandlingen $23 \%$ relativ og 7,2\% absolutt risikoreduksjon over fem år (4.), dvs. en NNT-verdi på 14 over fem år og 69 per år. Dette setter effekten av hjertestarterimplantasjon i perspektiv.

Disse studiene er gamle. Dagens pasienter får atskillig bedre medisinsk behandling, med redusert dødsrisiko til følge. Effekten av implanterte hjertestartere er derfor neppe større nå enn da de nevnte studiene ble gjort. I 2016 kom en stor dansk studie av effekten av primærprofylaktisk ICD-implantasjon hos pasienter med ikke-koronar, dilatert kardiomyopati, der overlevelseseffekten ikke var statistisk signifikant (5). Dette bremset nok veksten i implantasjonsraten.

En implantert hjertestarter kan redde en pasients liv. Men den eliminerer altså ikke risikoen for plutselig hjertedød. På gruppebasis er effekten moderat. Mange arytmidødsfall er uttrykk for en ikke-håndterbar grunnsykdom. Å intervenere med sjokk fra en implantert hjertestarter forlenger i slike tilfeller kun dødsprosessen. Nyman og medarbeidere kan naturligvis ikke si noe om pasientenes liv ble forlenget. Men det ville vært interessant å vite hva pasientene døde av, og om de fikk ICD-sjokk i livets sluttfase. En svensk studie viser at dette kan være et betydelig problem ( $\underline{6}$ ).

Forfatterne skal ha honnør for manuell gjennomgang av ni års implantasjonspraksis. Men kvalitetskontroll i ettertid avdekker eventuelle avvik og uheldig praksis flere år "for sent». Av hensyn til pasientsikkerheten burde all operativ virksomhet og eventuelle komplikasjoner følges løpende, for eksempel ved at man legger alle data inn i et register, som så analyseres regelmessig. På institusjonsnivå burde man registrere operatør, utstyr og fremgangsmåte. Registre over persondata krever tillatelser etter spesiell søknad. Slik godkjenning er det ikke alltid så enkelt å få. Tanken bak det restriktive regelverket er god. Men norsk «personvern» hever terskelen for å opprette enkle, løpende registreringer av kvaliteten på egen virksomhet og for å opprette detaljerte registre, slik f.eks. Danmark har for sin pacemakervirksomhet. Det burde man gjøre noe med. Kvalitetsovervåkning er nøkkelen til god pasientsikkerhet.

\section{LITTERATUR}

1. Nyman M, Molaug IC, Næss AM et al. Implantasjon av hjertestartere ved St.Olavs hospital 2006-15. Tidsskr Nor Legeforen 2020; 140. doi: 10.4045/tidsskr.20.0115. [CrossRef]

2. Wathen M. Implantable cardioverter defibrillator shock reduction using new antitachycardia pacing therapies. Am Heart J 2007; 153: 44-52. [PubMed][CrossRef]

3. Connolly SJ, Hallstrom AP, Cappato R et al. Meta-analysis of the implantable cardioverter defibrillator secondary prevention trials. AVID, CASH and CIDS studies. Antiarrhythmics vs Implantable Defibrillator study. Cardiac Arrest Study Hamburg. Canadian Implantable Defibrillator Study. Eur Heart J 2000; 21: 2071-8. [PubMed][CrossRef]

4. Bardy GH, Lee KL, Mark DB et al. Amiodarone or an implantable cardioverter-defibrillator for congestive heart failure. N Engl J Med 2005; 352: 225-37. [PubMed][CrossRef]

5. Køber L, Thune JJ, Nielsen JC et al. Defibrillator implantation in patients with nonischemic systolic heart failure. N Engl J Med 2016; 375: 1221-30. [PubMed][CrossRef]

6. Westerdahl AK, Sutton R, Frykman V. Defibrillator patients should not be denied a peaceful death. Int J Cardiol 2015; 182: 440-6. [PubMed][CrossRef] 
Publisert: 28. september 2020. Tidsskr Nor Legeforen. DOI: 10.4045/tidsskr.20.0674

(C) Tidsskrift for Den norske legeforening 2023. Lastet ned fra tidsskriftet.no 26. april 2023. 